\title{
Review
}

\section{Cheeses of Turkey: 2. Varieties ripened under brine}

\author{
Ali A. HAYAloglu ${ }^{1 *}$, Barbaros H. OZER ${ }^{2}$, Patrick F. Fox ${ }^{3}$ \\ ${ }^{1}$ Department of Food Engineering, Engineering Faculty, Inonu University, 44280 Malatya, Turkey \\ ${ }^{2}$ Department of Food Engineering, Agricultural Faculty, Harran University, 63300 Sanliurfa, Turkey \\ ${ }^{3}$ Department of Food and Nutritional Sciences, University College, Cork, Ireland
}

Received 16 July 2007 - Accepted 11 October 2007

\begin{abstract}
Although a large number of traditional brined cheese varieties are produced in Turkey, very few are manufactured on an industrial level. The most popular brined cheese in Turkey is Beyaz peynir; other varieties produced at substantial levels include Otlu, Mihalic, Urfa, Malatya, Gaziantep, Hellim, Orgu, Ezine and Dil. Local production of these cheeses has increased significantly and some of them can be found readily throughout Turkey. The volume of milk used in the manufacture of traditional cheese varieties in Turkey is fairly high. Therefore, there is a need to fully understand the microbiological, chemical and biochemical changes that occur in traditional cheeses during processing and/or ripening, so that industrialisation of these products would be possible. This review describes the manufacturing practices, and microbiological and biochemical/chemical properties of traditional Turkish brined cheeses. The description of Beyaz peynir is updated, but other brined varieties are discussed initially.
\end{abstract}

cheeses of Turkey / brine / white cheese / proteolysis / microbiology / ripening

\begin{abstract}
摘要 - 土耳其干酪 2: 盐水成熟干酪的种类。摘要 尽管在土耳其传统盐水干酪的 品种很多, 但工业化生产的品种较少。其中最受欢迎的是 Beyaz peynir 干酪, 其次是 Otlu、Mihalic、Urfa、Malatya、Gaziantep、Hellim、Orgu、Ezine 及 Dil 干酪。这些干酪在 当地的产量逐年增加, 有的干酪品种已经在全国范围内生产。在土耳其, 用于生产传统干酪 的原料奶的消耗量相当大。因此, 有必要全面地了解传统干酪加工和成熟过程中微生物、生 化和化学变化, 使这些产品的工业化生产成为可能。本文介绍了传统土耳其盐水平酪的制作 工艺, 以及其微生物学、生物化学特性。着重介绍了 Beyaz peynir 干酪的最新研究进展, 并 对其它品种的盐水干酪进行了回顾。
\end{abstract}

\section{土耳其干酪 / 盐水 / 白干酪 / 蛋白水解 / 微生物学 / 成熟}

Résumé - Fromages de Turquie : 2. Variétés affinées en saumure. Bien qu'un grand nombre de variétés traditionnelles de fromages affinés soient produites en Turquie, très peu d'entre elles le sont au niveau industriel. Le fromage affiné en saumure le plus populaire en Turquie est le Beyaz peynir; d'autres variétés produites à des niveaux substantiels incluent les fromages Otlu, Mihalic, Urfa, Malatya, Gaziantep, Hellim, Orgu, Ezine et Dil. La production locale de ces fromages a augmenté significativement et certains d'entre eux peuvent être trouvés facilement partout en Turquie. Le volume de lait utilisé dans la fabrication des variétés de fromage traditionnelles en Turquie est assez élevé.

*Corresponding author (通讯作者): ahayaloglu@inonu.edu.tr 
Il y a donc besoin de bien comprendre les changements microbiologiques, chimiques et biochimiques qui interviennent dans les fromages traditionnels au cours de la fabrication et/ou de l'affinage de façon à rendre possible l'industrialisation de ces produits. Cette revue décrit les pratiques technologiques et les propriétés microbiologiques et biochimiques/chimiques des fromages turcs traditionnels saumurés. La description du Beyaz peynir est actualisée, mais d'autres variétés saumurées sont présentées pour la première fois.

fromage de Turquie / saumure / pâte fraîche / protéolyse / microbiologie / affinage

\section{INTRODUCTION}

Brined cheeses are manufactured mainly in Mediterranean and Balkan countries, including Turkey. They are produced under different names, i.e., Beyaz peynir (Turkey), Feta (Greece), Bjalo Salamureno Sirene (Bulgaria), Domiati (Egypt), Teleme (Greece, Romania, Turkey), Iranian White (Iran) and Beli Sir U Kriskama (former Yugoslavia) [33]. Some local varieties ripened under brine are also produced in the above-mentioned countries. Some examples in Turkey are Urfa, Gaziantep, Malatya, Orgu, Mihalic, Ezine, Dil, Otlu and Hellim (Fig. 1); Sfela, Batzos, Kalathaki Limnou in Greece [9]; Gibna beyda in Sudan, Mish in Egypt, Nabulsi in Jordan, Mudaffara in Sudan and Middle Eastern countries, Akawi in Lebanon and Syria [2]. In general, these cheeses have no rind and a salty and slightly acidic taste which arise from storage in a dense brine (12 to $18 \% \mathrm{NaCl}$ ) and the action of lactic acid bacteria during ripening, respectively. Therefore, salt and acid are the critical parameters for conservation of these types of cheese and are checked periodically during maturation to ensure the quality of the cheese.

The cheeses were produced originally from sheep's or goats' milk, but recently, cows' milk or mixtures of these types of milk are used. Since the lactation period of sheep or goats is shorter than that of cows, the use of cows' milk has increased gradually. However, some types of brined cheeses are produced in Turkey from sheep's milk only. Ezine cheese is produced from milk of the Sakiz breed in Ezine county of Canakkale, which has obtained a designation "Controlled Geographical Origin”. Also, Urfa cheese is made traditionally from Awassi sheep's milk in the Sanliurfa region.

\section{BEYAZ PEYNIR (TURKISH WHITE BRINED CHEESE)}

\subsection{Chemical and technological aspects}

Beyaz peynir is the most popular cheese variety in Turkey, representing about $60 \%$ of the country's total cheese production; its manufacture dates back thousands of years [72]. The classical product is generally cubical or rectangular in shape with no rind [33]. Although no specific definition of Beyaz peynir is available in the Turkish Standards (TS) based on its moisture content, some researchers have defined the product as semi-hard [73,74] or semi-soft [19]. According to the present Turkish Standards, Beyaz peynir is divided into four groups based on the \% fat-in-dry matter (FDM):

- full-fat (minimum $45 \mathrm{~g} \cdot 100 \mathrm{~g}^{-1} \mathrm{FDM}$ );

- semi-fat (30-44 g.100 g ${ }^{-1}$ FDM);

- low-fat (20-29 g.100 g-1 FDM); and

- non-fat $\left(<20 \mathrm{~g} \cdot 100 \mathrm{~g}^{-1} \mathrm{FDM}\right)$.

The production technology and chemical, microbiological and biochemical properties of Beyaz peynir were reviewed by Hayaloglu et al. [33]. The manufacturing protocol for Beyaz peynir shows similarities to Feta cheese-making, with slight differences. Cows', sheep's, goats' milk or 


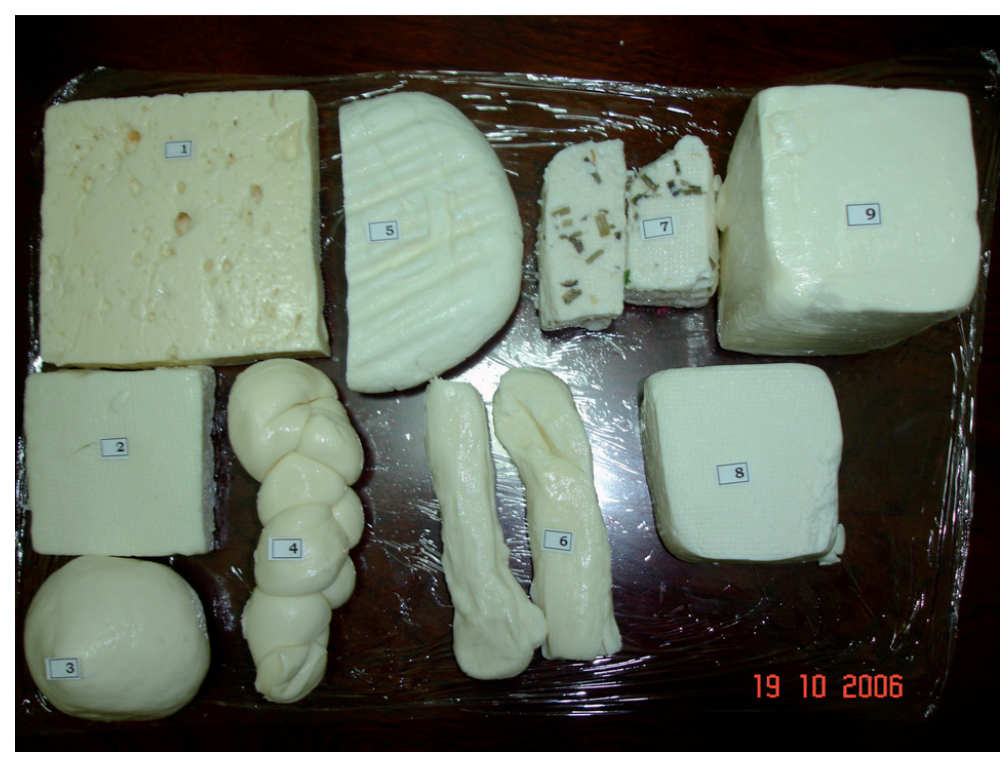

Figure 1. Some varieties of brined cheeses produced in Turkey. 1: Mihalic, 2: Ezine, 3: Urfa, 4: Diyarbakir Orgu, 5: Malatya, 6: Dil, 7: Otlu, and 8, 9: Beyaz peynir.

mixtures of these are used in the manufacture of Beyaz peynir. The average yield of Beyaz peynir made from sheep's milk is $26-28 \mathrm{~kg} \cdot 100 \mathrm{~kg}^{-1}$ [20], while the yield from goats' or cows' milk is 15$16 \mathrm{~kg} \cdot 100 \mathrm{~kg}^{-1}$ [33]. Raw milk is used widely in the manufacture of classical Beyaz peynir by small dairies but, in some parts of Turkey, where hot climatic conditions prevail, the product is made from heat-treated milk (e.g., $65-68{ }^{\circ} \mathrm{C}$ for $5-$ $30 \mathrm{~min}$ or $80{ }^{\circ} \mathrm{C}$ for $1-2 \mathrm{~min}$ ) [72]. In industrial-scale cheese-making, raw milk has largely been replaced by pasteurised milk ( $72{ }^{\circ} \mathrm{C}$ for $\left.15 \mathrm{~s}\right)$ [71].

Standardisation of the casein-to-fat $(\mathrm{C}: \mathrm{F})$ ratio is not common in classical Beyaz peynir production but it is widely employed in industrial production; for a high quality Beyaz peynir, a $\mathrm{C}: \mathrm{F}$ ratio of 0.8:0.9 was reported to be optimum [7]. To the best of our knowledge, increasing the total solids level in cheese milk is not used in industrial Beyaz peynir production.
Yetismeyen [82] reported that proteolysis in Beyaz peynir produced from UFconcentrated milk was slowed down, leading to a longer ripening period to attain the desired organoleptic characteristics in the final product.

The milk used in the production of Beyaz peynir is generally coagulated by commercial calf rennet, but the increased consumption of cheese has led to an increase in the demand for rennet while there has been a decrease in the number of young animals available for slaughter to produce the enzyme extract [64]. Therefore, other suitable coagulants, including proteinases from microorganisms, have become more popular in the manufacture of Beyaz peynir (Tab. I).

Salting is another factor affecting the composition and ripening of Beyaz peynir. In general, the higher the level of $\mathrm{NaCl}$ in brine, the lower the rate of proteolysis in Beyaz peynir [55, 72]. Guven et al. [28] ripened Beyaz peynir in brine containing 
Table I. Impact of milk coagulant on the properties of Beyaz peynir.

\begin{tabular}{|c|c|c|}
\hline Coagulant & Impact on cheese & References \\
\hline $\begin{array}{l}\text { Fromase and Rennilase using } \\
\text { Rizomuchor miehei }\end{array}$ & $\begin{array}{l}\text { No effect on cheese yield, acidity, dry } \\
\text { matter or fat but faster proteolysis. }\end{array}$ & Yesilyurt [81] \\
\hline $\begin{array}{l}\text { Microbial coagulant using } \\
R \text {. miehei }\end{array}$ & $\begin{array}{l}\text { Proteolysis faster (ripening index of } \\
24.0 \% \text { ) than cheese made using calf } \\
\text { rennet (ripening index of } 16.2 \% \text { ). }\end{array}$ & $\begin{array}{l}\text { Yetismeyen et al. } \\
{[84]}\end{array}$ \\
\hline $\begin{array}{l}\text { Fromase } 46 \mathrm{~T} \text { (using } R \text {. miehei) } \\
\text { Rennilase } 150 \mathrm{~L} \text { (using } R \text {. miehei) } \\
\text { Maxiren } 50 \text { (using Kluyveromyces marxianus } \\
\text { var. lactis by recombinant DNA technology) } \\
\text { Liquid commercial rennet } \\
\text { (90\% chymosin and } 10 \% \text { pepsin) }\end{array}$ & $\begin{array}{l}\text { The fastest ripening was obtained in } \\
\text { the cheese made from Fromase } \\
\text { followed by Rennilase, calf rennet and } \\
\text { Maxiren. }\end{array}$ & $\begin{array}{l}\text { Saldamli and } \\
\text { Kaytanli [64] }\end{array}$ \\
\hline $\begin{array}{l}\text { Chicken pepsin or mixtures } \\
(50: 50 \text { or } 70: 30) \text { of chicken } \\
\text { pepsin and calf rennet }\end{array}$ & $\begin{array}{l}\text { No differences observed in the sensory } \\
\text { and overall chemical quality of the } \\
\text { cheeses. }\end{array}$ & Uysal et al. [78] \\
\hline
\end{tabular}

$12,14,16$ or $18 \mathrm{~g} \mathrm{NaCl} \cdot 100 \mathrm{~g}^{-1}$ water at $7{ }^{\circ} \mathrm{C}$ for 9 weeks. The authors found that the brine concentration affected the $\mathrm{pH}$, TCA-soluble nitrogen and hydrolysis of $\beta$ casein, but showed no effect on the level of water-soluble nitrogen and the hydrolysis of $\alpha_{\mathrm{s} 1}$-casein. The organoleptic properties of cheese ripened in a $12 \mathrm{~g} \mathrm{NaCl} \cdot 100 \mathrm{~g}^{-1}$ brine was the most preferred. Alternative salting methods (i.e., adding salt to the milk or the curd before pressing) or partially substituting $\mathrm{NaCl}$ by other salts, such as $\mathrm{KCl}$ or $\mathrm{MgCl}_{2}$, have been found to be promising in laboratory-scale Beyaz peynir production but these methods are not common yet in industrial applications $[4,26$, 27].

\subsection{Microbiological and biochemical aspects}

Lactic acid bacteria are predominant in Beyaz peynir, and the main isolates are Lactococcus lactis subsp. lactis, Lc. lactis subsp. cremoris, Lactobacillus casei subsp. casei, Enterococcus faecalis var. liquefaciens and Leuconostoc paramesenteroides (now Weisella paramesenteroides) with Lc. lactis subsp. lactis, at $2.6 \times 10^{6} \mathrm{cfu} \cdot \mathrm{g}^{-1}$, being the dominant species encountered [36]. With continued ripening, the numbers of lactococci decrease and species of lactobacilli (e.g. Lb. casei subsp. casei) become dominant in Beyaz peynir. A similar trend in the profile of lactic acid bacteria of Beyaz peynir was observed by Karakus et al. [45].

Many species of starter microorganisms have been used in the manufacture of classical Beyaz peynir, and many combinations have been tested to establish the best match of composition and properties with the characteristics of this variety of cheese [24]. Determination of the technological properties of the natural flora of cheese is important in the selection of a balanced combination of starter bacteria to obtain the best texture, aroma/flavour and body in cheese. The enzymatic activities of the natural lactic flora should be the prime criterion in deciding the starter bacteria for cheese-making. Durlu-Ozkaya et al. [16] isolated the dominant lactic acid bacteria in mature Beyaz peynir made from ewe's milk and evaluated the technological properties of the isolated bacteria. These authors concluded that whole cells of Lc. lactis subsp. lactis and enterococci showed 
lipolytic and proteolytic activities. Strains differed in terms of their acidifying and caseinolytic activity. Most of the enterococci isolates showed tyrosine decarboxylase activity; lactobacilli exhibited weak antibacterial activity against food-borne pathogens. Similarly, Karakus [44] found that Lc. lactis subsp. lactis and citratepositive Lc. lactis subsp. lactis isolated from Beyaz peynir had strong acidifying activity but the acid-producing capacity of Lb. casei and Lb. plantarum isolated from the same samples was weak. Karakus [44] also noted that the proteolytic activity of lactobacilli was lower than that of lactococci. Gursel et al. [23] investigated the potential of freeze-shocked thermophilic Lactobacillus species (Lb. delbrueckii subsp. bulgaricus or Lb. helveticus) as adjunct cultures for Beyaz peynir production. They demonstrated that ripening was accelerated by the incorporation of freezeshocked Lactobacillus spp., especially $L b$. helveticus, without impairing the body and texture of the final product. It was reported that $L b$. sake LS-9 used in combination with Lc. lactis ssp. lactis in the manufacture of Beyaz peynir produced a good quality cheese unless the level of inoculum was high [5]. Recently, Yilmaztekin et al. [85] investigated the potential of incorporating Bifidobacterium BB-12 and Lb. acidophilus LA-5 as adjunct cultures in Beyaz peynir production. The authors reported that the numbers of both probiotic bacteria decreased gradually throughout the 90day ripening. However, Kasimoglu et al. [46] maintained that the counts of $\mathrm{Lb}$. acidophilus were high enough for a claimed therapeutic effect in vacuum-packed Beyaz peynir.

The combinations of starter cultures used in the production of Beyaz peynir are listed in Table II. Some strains of Lc. lactis subsp. lactis and subsp. cremoris are salttolerant and have high proteolytic activity and/or acid-forming capacity, but yoghurt starter bacteria and most species of lactococci die out early during the maturation of Beyaz peynir.

Recently, Hayaloglu [29], who compared the performance of four single strains of lactococci (UC317, NCDO763, HP or SK11) used as starters in the manufacture of Beyaz peynir, found no difference between the cheeses in terms of acid degree value (ADV) but the development of $\mathrm{pH}$ and proteolysis (soluble nitrogen fractions) in the cheeses made with these strains were different during $90 \mathrm{~d}$ of ripening. Each strain of Lactococcus contributed to proteolysis in different ways and released different levels of soluble nitrogen and free amino acids in the cheese matrix [29]. Qualitatively and quantitatively different peptide profiles in the $\mathrm{pH}$ 4.6soluble fraction were evident of Beyaz peynir made with different strains of lactococci, as shown Figure 2 [34]. It was proposed that the different peptide profiles were due to different cell envelopeassociated proteinases in the lactococcal strains used. Urea-PAGE of the pH 4.6insoluble fraction of Beyaz peynir made with defined strains of lactococci indicated that $\alpha_{\mathrm{s} 1}$-casein was hydrolysed more rapidly than $\beta$-casein [34]. However, only slight differences between cheeses made with different strains of lactococci were detected by urea-PAGE (Fig. 3). Hayaloglu et al. [35] investigated the influence of various Lactococcus strains on biochemical changes in Beyaz peynir throughout ripening. The level of peptides in the cheeses increased throughout ripening as determined by RP-HPLC of the $70 \%$ ethanol-soluble or -insoluble fractions of the cheeses and the cheeses were grouped by principal component analysis (PCA) and hierarchical cluster analysis (HCA) based on the type of starter and stage of ripening (Fig. 4). The use of a starter culture and the strain of starter influenced the individual amino acid profile of Beyaz cheese [35]; Leu, Glu, Phe, Lys and Val were the 
Table II. Starter organisms used in the manufacture of Beyaz peynir (with permission of Toufeili and Ozer [72]).

\begin{tabular}{|c|c|}
\hline Blends of organisms & $\begin{array}{l}\text { Inoculation level } \\
\left(\mathrm{mL} \cdot 100 \mathrm{~mL}^{-1}\right)\end{array}$ \\
\hline Ent. durans $41770+$ Lb. delbrueckii subsp bulgaricus $\mathrm{CH} 2$ & 1.0 \\
\hline $\begin{array}{l}\text { Lc. lactis subsp. lactis }+ \text { Lc. lactis subsp. cremoris }+ \\
\text { Leu. mesenteroides subsp. cremoris }\end{array}$ & $\mathrm{NR}^{1}$ \\
\hline Lc. lactis subsp. lactis + Lc. lactis subsp. cremoris + Lb. sake & 1.0 \\
\hline Lc. lactis subsp. lactis + Lc. lactis subsp. cremoris + Lb. plantarum & $1-2.0$ \\
\hline Lb. delbrueckii subsp. bulgaricus + Str. thermophilus $(1: 1)$ & $0.5-1.0$ \\
\hline Lc. lactis subsp. lactis + Lc. lactis subsp. cremoris & 2.0 \\
\hline $\begin{array}{l}\text { Lc. lactis subsp. lactis + Lc. lactis subsp. lactis biovar. diaceytlactis }+ \\
\text { Lb. casei }(1: 1: 1)\end{array}$ & 2.0 \\
\hline Lb. casei + Lc. lactis subsp. lactis $(1: 1)$ & $0.5-2.0$ \\
\hline Lc. lactis subsp. lactis $\mathrm{S} 1+$ Lb. plantarum $\mathrm{L} 8+$ Ent. durans $\mathrm{C} 2 \mathrm{O}$ & NR \\
\hline $\begin{array}{l}\text { Lc. lactis subsp. lactis } \mathrm{CH}+\text { Ent. durans } \mathrm{CH}+\text { Ent. faecalis } \mathrm{CH}+ \\
\text { Lb. delbrueckii subsp. lactis } \mathrm{CH}\end{array}$ & NR \\
\hline $\begin{array}{l}\text { Lc. lactis subsp. cremoris }+ \text { Lc. lactis subsp. lactis }(\mathrm{R} 707)+ \\
\text { Lb. helveticus } \mathrm{LH} 100^{2}+\text { Lb. delbrueckii subsp. bulgaricus } \mathrm{LB} 12^{2}\end{array}$ & NR \\
\hline Lc. lactis subsp. cremoris + Lc. lactis subsp. lactis + Lb. casei & 2.0 \\
\hline $\begin{array}{l}\text { Lc. lactis subsp. lactis }+ \text { Lc. lactis subsp. cremoris }+ \text { Bif. bifidum } \\
\text { BB12 + Lb. acidophilus LA5 }\end{array}$ & 1.0 \\
\hline
\end{tabular}

predominant amino acids in all cheeses at day 60 (Fig. 5).

High lipolytic activity in Beyaz peynir is not a characteristic property, but the use of weakly lipolytic strains of the lactic acid bacteria is desirable. Guler and Uraz [21] found that myristic $\left(\mathrm{C}_{14}\right)$, palmitic $\left(\mathrm{C}_{16}\right)$, stearic $\left(\mathrm{C}_{18}\right)$ and oleic $\left(\mathrm{C}_{18: 1}\right)$ acids were the principal free fatty acids in commercial Beyaz peynir samples $(n=30)$. More recently, Ozer et al. [55] demonstrated that the level of long-chain free fatty acids in Beyaz peynir made with $L c$. lactis subsp. lactis and subsp. cremoris plus microencapsulated $B$. bifidum BB-12 and $L b$. acidophilus LA-5 as adjunct cultures was much higher than the short- or medium chain FFAs.

Akalin et al. [3] who evaluated the contribution of organic acids to flavour development in Beyaz peynir throughout
12 months of ripening, found that lactic acid accounted for $95 \%$ of the total organic acids during the early stages of ripening, but after 9 and 12 months of ripening, butyric acid constituted 20 and $27 \%$, respectively, of the total organic acids in the same cheeses.

Kaptan et al. [42] monitored the accumulation of biogenic amines in Beyaz peynir made by incorporating E. faecium and E. faecalis, combined with a commercial lactococcal culture over a 6-month period. During ripening, the concentrations $\left(\mathrm{mg} \cdot \mathrm{kg}^{-1}\right)$ of biogenic amines varied as follows: cadaverine, 62.25-87.95; putrescine, 83.38-88.51; phenylethylamine 52.94-127.74; tyramine, 172.34-273.25 and tryptamine, 13.05-17.07. With the exception of phenylethylamine, none of the biogenic amines exceeded its toxic threshold. 


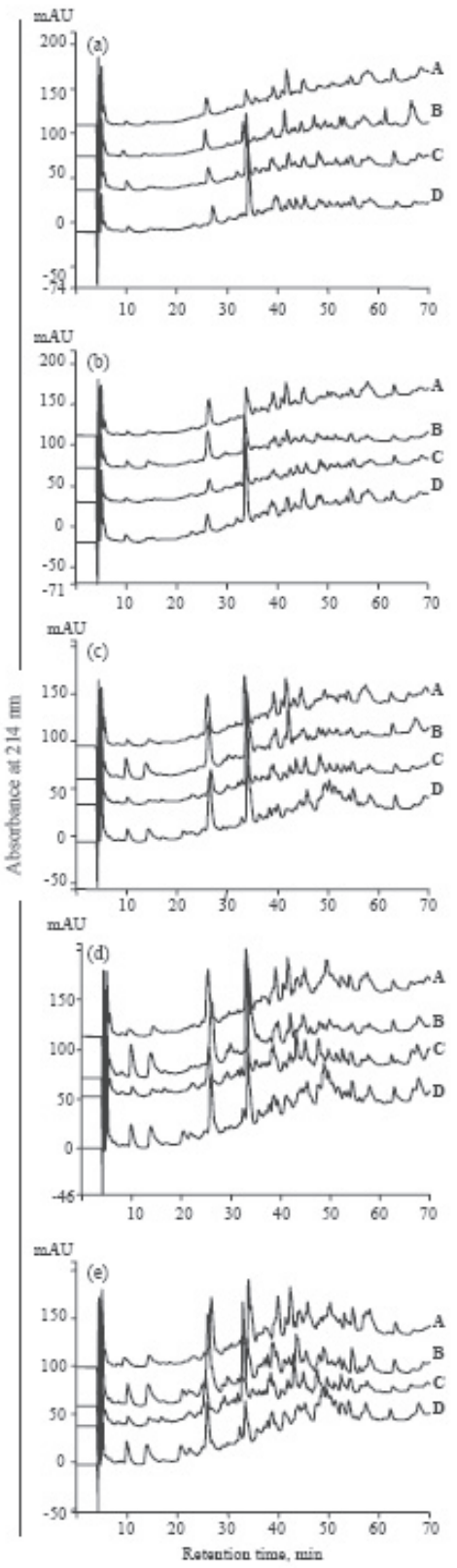

Figure 2. RP-HPLC profiles of the $\mathrm{pH}$ 4.6-soluble fraction of Beyaz peynir made using: A: Lc. lactis subsp. lactis UC317; B: Lc. lactis subsp. lactis NCDO767; C: Lc. lactis subsp. cremoris HP or D: Lc. lactis subsp. cremoris SK11 after 1 (a), 15 (b), 30 (c), 60 (d) and 90 (e) days of ripening. (From Hayaloglu et al. [34], reprinted by permission of International Dairy Journal, Copyright (C) Elsevier B.V., 2004.) 

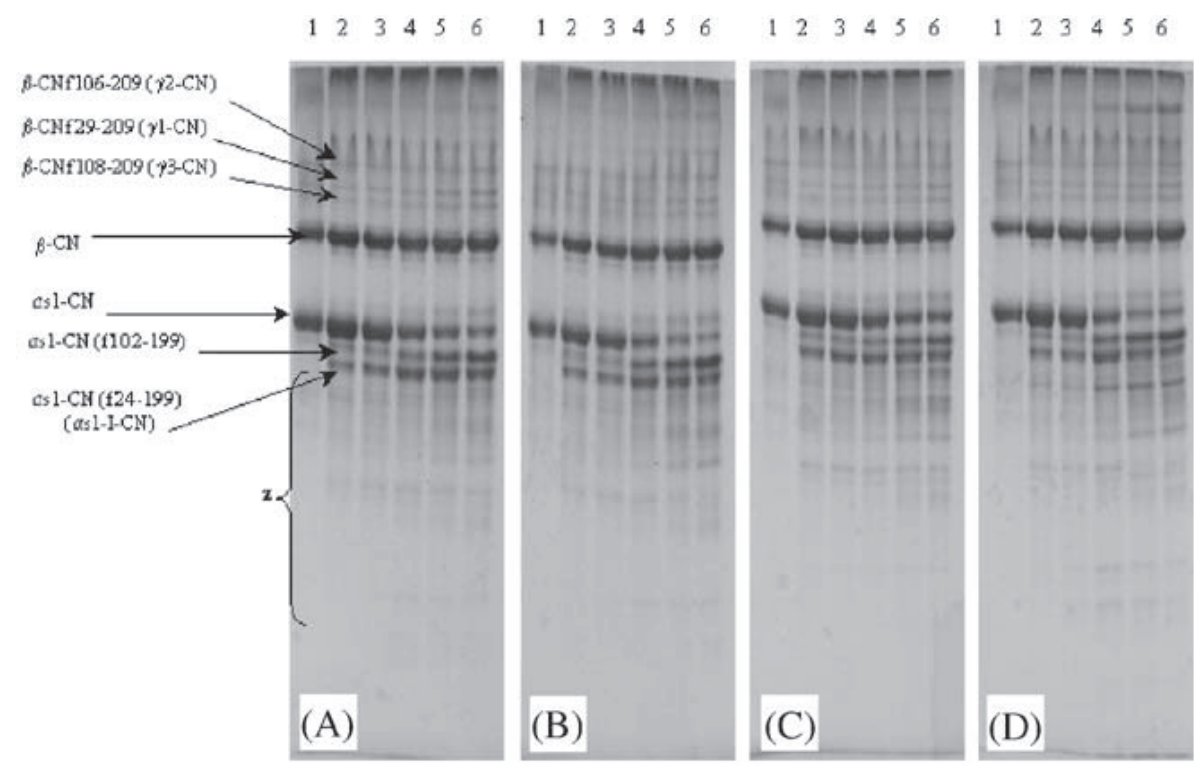

Figure 3. Urea-polyacrylamide gel electrophoretograms of the $\mathrm{pH}$ 4.6-insoluble fraction of Beyaz peynir made using: (A) Lc. lactis subsp. lactis UC317; (B) Lc. lactis subsp. lactis NCDO763; (C) Lc. lactis subsp. cremoris HP or (D) Lc. lactis subsp. cremoris SK11. Lane 1: Na-caseinate; lanes 2-6: cheeses after 1, 15, 30, 60 or 90 days of ripening, respectively. (From Hayaloglu et al. [34], reprinted by permission of International Dairy Journal, Copyright (c) Elsevier B.V., 2004.)

\section{OTLU CHEESE (HERBY CHEESE)}

Otlu cheese is a very famous brined cheese variety in Turkey and its popularity has been increasing gradually. The cheese has long been produced traditionally in eastern cities, particularly in Van province. Otlu cheese is produced using herbs which give the cheese a characteristic appearance and aroma/flavour. These herbs belong to the species of Allium, Thymus, Silene, Ferula, and Anthriscus nemorosa, the local names of which are, Sirmo, Kekik, Siyabo, Heliz and Mendo, respectively $[14,69]$. Addition of herbs to the cheese is an essential step in the production process in order to obtain a characteristic flavour or to extend the shelflife of the cheese. Otlu cheese is ripened in brine or in earthenware or plastic containers using dry-salting. In the past, dry- salted cheeses were ripened underground; however, at present, this method of salting has been replaced by brining $[14,17]$. It was reported that the use of different herbs and their level significantly influence the chemistry, biochemistry and sensory characteristics of Otlu cheese. The manufacturing technology and its characteristics were reviewed extensively by Hayaloglu and Fox [31].

\section{URFA CHEESE}

Urfa is a brined, semi-hard cheese variety, produced particularly in the southeast of Turkey. The cheese is made from raw sheep's or cows' milk or a mixture of these milks [57]; it has a conical shape, a salty taste and a white colour. It has gained an economic value and popularity and 

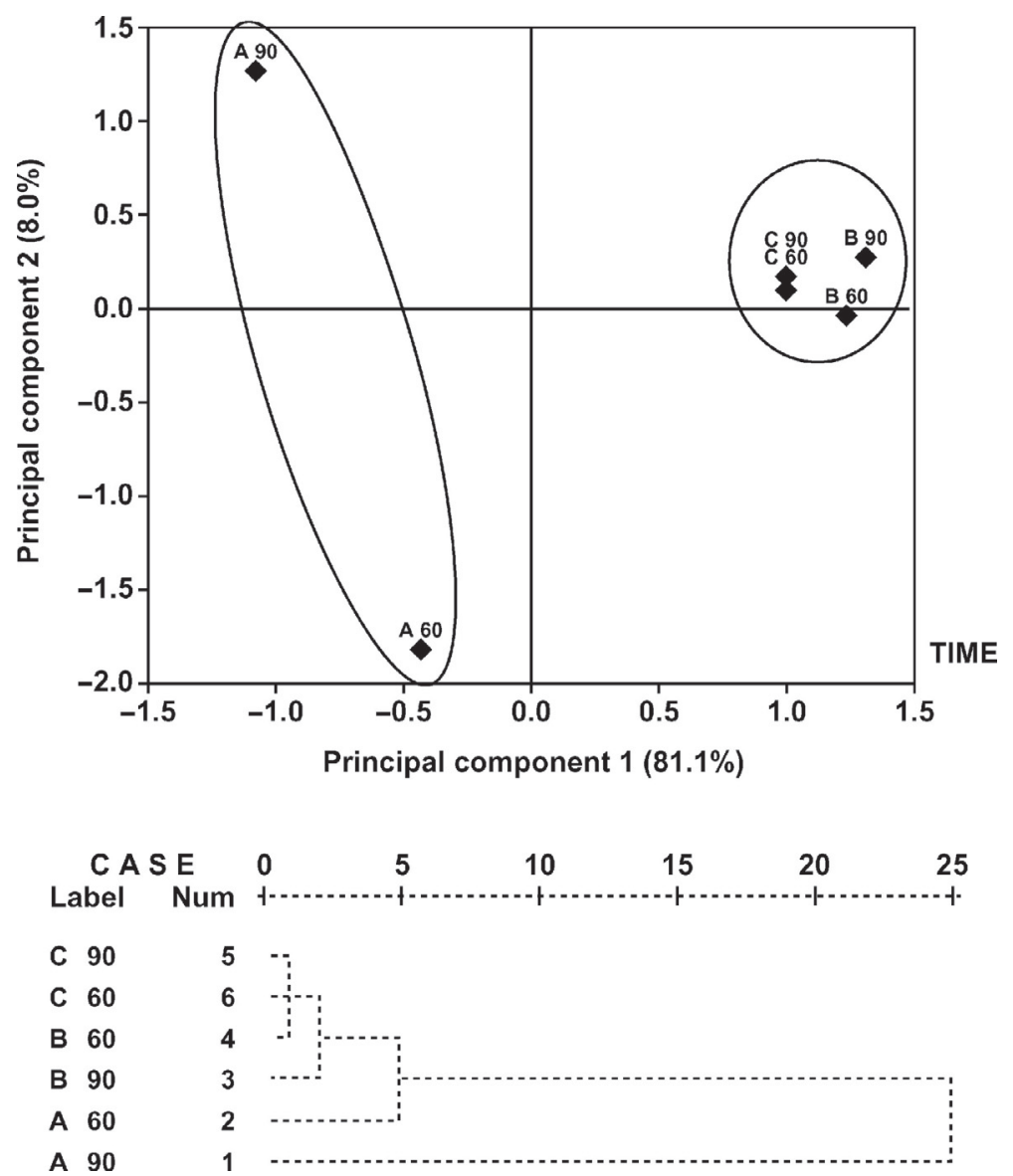

Figure 4. Principal component (top) and hierarchical cluster (bottom) analyses of chromatographic data from RP-HPLC profiles of the 70\% ethanol-insoluble fractions of Beyaz peynir made with starter culture systems SF (A), 763SK11 (B), and 317HP (C). Cheeses: SF = starter free; 763SK11 $=$ L. lactis ssp. lactis $\mathrm{NCDO} 763$ plus L. lactis ssp. cremoris $\mathrm{SK} 11 ; 317 \mathrm{HP}=$ L. lactis ssp. lactis UC317 plus L. lactis ssp. cremoris HP. (From Hayaloglu et al. [35], reprinted by permission of Journal of Dairy Science.)

can easily be found in markets throughout Turkey. In the traditional production method, raw milk is coagulated using calf rennet at $30-32{ }^{\circ} \mathrm{C}$ for 45 to $60 \mathrm{~min}$; the coagulum is cut into $1 \mathrm{~cm}$ cubes and then drained in triangular moulds, called "parzin", which contain 250-400 g of curd. The parzins have finer pores than regular cheese cloth and whey removal may not be complete in less than $12 \mathrm{~h}$ at room temperature. Following gravity drainage, the cheese blocks are scalded in their own whey at $90-95{ }^{\circ} \mathrm{C}$ for about 2 3 min to make the cheese more elastic and safer. Afterwards, the cheese blocks are dry-salted overnight at room temperature and transferred to brine containing $15 \% \mathrm{NaCl}[57,59]$. The mean chemical composition of ripened and unripened Urfa cheese is given in Table III. Substantial variations have been reported in the salt and dry matter content of Urfa cheese 


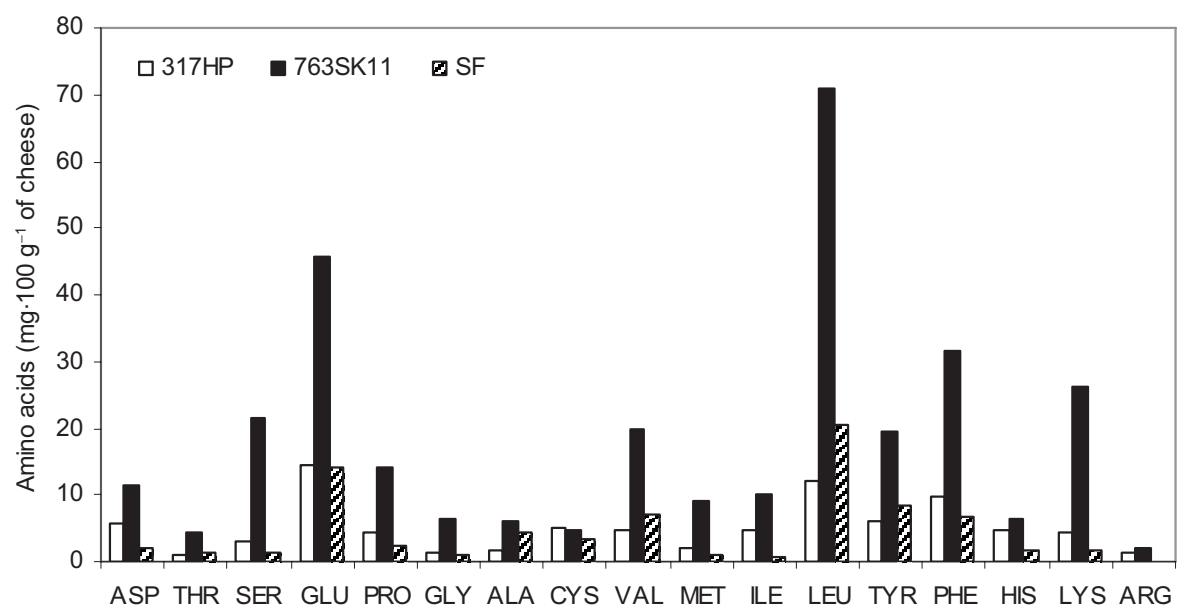

Figure 5. Concentrations of individual free amino acid in 60 days-old Beyaz peynir made with starter culture systems 317HP (open bars), 763SK11 (solid bars), and SF (striped bars). Cheeses: $\mathrm{SF}=$ starter free; $763 \mathrm{SK} 11=$ L. lactis ssp. lactis $\mathrm{NCDO} 763$ plus L. lactis ssp. cremoris SK11; $317 \mathrm{HP}=$ L. lactis ssp. lactis UC317 plus L. lactis ssp. cremoris HP. (From Hayaloglu et al. [35], reprinted by permission of Journal of Dairy Science.)

Table III. Chemical composition and $\mathrm{pH}$ of ripened and unripened Urfa cheese.

\begin{tabular}{lrrrr}
\hline & \multicolumn{2}{c}{ Unripened cheese $(n=29)^{1}$} & \multicolumn{2}{c}{ Ripened cheese $(n=44)^{2}$} \\
\cline { 2 - 5 } Variables & Range & Mean & Range & Mean \\
\hline Dry matter (\%) & $27.3-47.9$ & 36.5 & $36.5-64.3$ & 50.1 \\
Fat (\%) & $4.1-27.8$ & 17.7 & $13.1-30.1$ & 23.2 \\
Fat-in-dry matter (\%) & $12.0-64.1$ & 47.0 & $35.9-72.4$ & 46.5 \\
Protein (\%) & $10.8-26.4$ & 16.8 & $9.1-28.8$ & 17.0 \\
Salt (\%) & $0.1-0.3$ & 0.2 & $2.8-11.5$ & 7.8 \\
pH & $4.5-6.0$ & 4.9 & $4.0-6.9$ & 5.3 \\
Titratable acidity & $0.3-1.2$ & 0.9 & $0.2-1.3$ & 0.7 \\
WSN $^{4}$ & - & - & $2.6-26.3$ & 9.6 \\
TCA-SN $^{4}$ & - & - & $3.5-7.5$ & 5.1 \\
PTA-SN $^{4}$ & - & - & $0.6-5.7$ & 3.0 \\
\hline
\end{tabular}

${ }^{1}$ From Akin and Sahan [6].

${ }^{2}$ From Atasoy and Akin [11].

${ }^{3}$ Expressed as g lactic acid per $100 \mathrm{~g}$ of cheese.

${ }^{4}$ Expressed as \% of total nitrogen.

during ripening. The cheese is very salty with a salt-in-dry matter content in the range 21 and $23 \%$ at day 90 [58]. Limited proteolysis occurs in Urfa cheese, probably due to scalding of the cheese curd and/or the high concentration of $\mathrm{NaCl}[11$,
55, 58, 59]. Microbial counts are quite high in Urfa cheeses made from raw milk; total bacterial counts are $9.7 \mathrm{log} \mathrm{cfu} \cdot \mathrm{g}^{-1}$ at $1 \mathrm{~d}$ and $8.1 \log \mathrm{cfu} \cdot \mathrm{g}^{-1}$ at $90 \mathrm{~d}$. Total bacterial counts are reduced by pasteurizing the cheese milk to $6.8 \mathrm{log} \mathrm{cfu} \cdot \mathrm{g}^{-1}$, 
by scalding of the curd to $7.2 \log \mathrm{cfu} \cdot \mathrm{g}^{-1}$ and a combination of these processes to $5.4 \log \mathrm{cfu} \cdot \mathrm{g}^{-1}$ [55]. Scalding of the curd at $95^{\circ} \mathrm{C}$ for $3 \mathrm{~min}$ reduces the counts of some pathogens, including Yersinia enterocolitica, Escherichia coli O157:H7, Shigella flexineri and Salmonella enteritidis during the early stage (30 d) of ripening; however, the growth of Staphyloccus aureus and Bacillus cereus is not affected by scalding of the curd or by brine concentration (12.5, 15.0 or $17.5 \%$ ) [59]. The authors concluded that the high concentration of $\mathrm{NaCl}$ $(\geqslant 15 \%)$ may suppress the development of the desired cheese aroma/texture characteristics. Also, it is not always possible to prevent the growth of pathogens by brining or scalding. Therefore, they recommended that pasteurized milk with a suitable starter culture should be used and precautions should be taken to avoid contamination during milking, transportation and all stages of cheese-making. Ozer et al. [58], who used ultrafiltration in the manufacture of Urfa cheese, found that this technique produced a cheese comparable with cheese made using the scalding method in terms of texture and structure.

\section{HELLIM CHEESE}

Hellim or Halloumi cheese is produced mainly in Cyprus but also in Middle Eastern countries (Syria, Lebanon, etc.), Greece and Southern Turkey [37, 63]. Currently, the cheese has international merit [62]. Hellim cheese has a semi-hard and elastic texture, a slight rind, no holes or openings. It is easily sliceable and its colour varies from white (when sheep's or goats' milk is used) through yellowish (when cows' milk is used in its production) $[22,51]$. Typical Hellim cheese is manufactured from either sheep's or goats' milk or mixtures of these two milks, but cows' milk is commonly used for its production, probably due to the scarcity of sheep's or goat's milk in the production area $[10,61]$. The fresh cheese has a characteristic flavour and is preserved in brine for more than $30 \mathrm{~d}$. The manufacturing procedure for Hellim is similar to that for Cypriot Halloumi cheese (for details refer to Papademas [60]). Hellim cheese is sold in the markets as vacuum-packaged pieces weighing ca. $250 \mathrm{~g}$. The chemical composition of Hellim made from raw or pasteurized milk is: moisture, $46.1 \%$ and $43.6 \%$; fat, $25.6 \%$ and $28.6 \%$; fat-in-dry matter, $47.5 \%$ and $50.7 \%$; $\mathrm{pH}, 6.0$ and 5.7 ; salt, $3.9 \%$ and $3.4 \%$; protein, $19.3 \%$ and $19.6 \%$; WSN (as \% of total N), $4.6 \%$ and $5.5 \%$, respectively [22]. Guven et al. [25], who studied the effect of rennet concentration on proteolysis in Hellim, showed that $\alpha_{\mathrm{s} 1}$-casein is degraded slowly during $60 \mathrm{~d}$ of ripening, but $\beta$-casein is hydrolyzed more rapidly than $\alpha_{\mathrm{s} 1}$-casein; this may be attributed to high $\mathrm{pH}$ (6.4-6.5) of Hellim cheese [25].

\section{MALATYA CHEESE}

Malatya cheese is made traditionally from raw sheep's or cows' milk or mixtures of these milks, and no starter culture is used. The traditional cheese-making practice is still used in farms and villages. Recently, some cheesemakers have used pasteurized milk and added a starter culture to standardize production. Scalding at $80-90{ }^{\circ} \mathrm{C}$ is the usual practice in Malatya cheese-making which gives the curd an elastic and compact texture after pressing; the physical, chemical and sensory characteristics of the cheese are also affected by scalding. The manufacturing protocol for the cheese is similar to that for Hellim, with minor differences. In the traditional method, raw cows' milk is coagulated at $32{ }^{\circ} \mathrm{C}$ using calf rennet in about $45 \mathrm{~min}$. The coagulum is cut into $1-2 \mathrm{~cm}$ cubes and stirred for about $30 \mathrm{~min}$, and then transferred to cloth bags and left to 
drain for $30 \mathrm{~min}$ without pressing. The bags, which contain approx. $250 \mathrm{~g}$ of curd, are tied up and moulded as a ball, and then pressed between wooden blocks for $2 \mathrm{~h}$. The cheeses are scalded at 85 to $90{ }^{\circ} \mathrm{C}$ for 3 to $5 \mathrm{~min}$ by means of dipping in their own whey and the cheese blocks are then re-pressed between the wooden blocks for $3 \mathrm{~min}$ and cooled immediately to room temperature. Afterwards, the cooled blocks are immersed in brine $(10-12 \% \mathrm{NaCl})$ and ripened in metal or plastic containers for at least $60 \mathrm{~d}$ at $6-$ $8{ }^{\circ} \mathrm{C}$. Malatya cheese can also be consumed fresh and unsalted. Fresh Malatya cheese is semi-hard, with no openings or holes, is elastic and sliceable. Its taste is milky or creamy and is yellowish in colour. The chemical composition of cheese made from raw or pasteurized milk is as follows: moisture $60.6 \%$ and $60.2 \%$, fat-indry matter $44.7 \%$ and $43.3 \%$, salt $2.7 \%$ and $2.2 \%$, protein $15.2 \%$ and $14.6 \%, \mathrm{pH} 6.0$ and 5.7, respectively (Hayaloglu et al., unpublished). Hayaloglu and Brechany [30], who investigated the influence of pasteurization prior to cheese-making and scalding temperature $\left(60,70,80\right.$ or $\left.90{ }^{\circ} \mathrm{C}\right)$ on the volatiles formed in Malatya cheese during ripening, found that raw milk cheese contained higher levels of acids, esters and lactones and lower levels of aldehydes and sulfur compounds than pasteurized milk cheeses. Raw milk cheeses contained higher levels of pentanoic acid, 2-methyl propanoic acid, 2-propen-1-ol, 2-propenal, 3-methylbutyl butanoate and 1-hydroxy 2propanone than pasteurized milk cheeses at the end of ripening. The results suggested that the pasteurization of cheese milk had a greater effect on the volatiles in cheese than the scalding temperature [30].

\section{MIHALIC (KELLE) CHEESE}

Mihalic is made from raw sheep's milk in Bursa and Balikesir provinces. The name "Mihalic" is an old name of
Karacabey, county of Bursa, and it is known that the cheese has been produced in these areas for at least 250 years. Mihalic is a hard, brined cheese, is slightly acidic, very salty, has regular openings (2$4 \mathrm{~mm}$ ) and a 3-4 mm rind [41,76]. Raw or pasteurized sheep's milk is coagulated at 32-35 ${ }^{\circ} \mathrm{C}$ using home-made calf or commercial rennet in wooden barrels named "polim" of 100-250 L capacity. Coagulation requires 60 to $90 \mathrm{~min}$ and the coagulum is cut into pieces the size of a grain of rice using a nailed wooden rod. The curds are stirred continuously and rested for 10-15 min. Then, the curds are cooked gradually at $45^{\circ} \mathrm{C}$ by adding boiling water and rested for another 10-15 min. Afterwards, the curds are transferred to a cotton cloth for whey drainage; the cloth is tied up and hung for complete draining which takes $3-8 \mathrm{~h}$. Nowadays, the curd is pressed using $50 \mathrm{~kg}$ weights for each $250 \mathrm{~kg}$ of cheese milk, probably to shorten the draining period. The cloth containing the curd is pierced periodically with a needle to accelerate wheying off. The formation of regular openings in the cheese occurs at this stage and this is one of the unique characteristics of Mihalic. The drained curd is cut into $3-5 \mathrm{~kg}$ blocks and brined in $18 \% \mathrm{NaCl}$ for $3 \mathrm{~d}$, then in $20 \% \mathrm{NaCl}$ for the next $2 \mathrm{~d}$ and finally in $22 \% \mathrm{NaCl}$ for 15-30 d. The cheese blocks are placed carefully on the bottom of a wooden barrel containing a layer of coarse salt; then the cheese blocks are covered with 20$22 \% \mathrm{NaCl}$ brine and the barrels are closed with a wooden lid. The cheese is ripened in the barrels in a cold room for about 3 months [53, 65, 77]. Mihalic is sold as vacuum-packed pieces weighing about 250 to $300 \mathrm{~g}$. The yield in Mihalic is $20-22 \%$ from sheep's milk [18] or 10-12\% from cows' milk $[53,71]$. The chemical composition of the cheese is given in Table IV. The cheese is characterized by high levels of salt and dry matter; the high level of salt delays ripening of the cheese (WSN (as \% 
Table IV. Chemical composition and pH of unripened ( 1 or 2 d) and ripened (90 d) Mihalic cheese.

\begin{tabular}{lrrrr}
\hline & & Ozcan $[53]^{1}$ & \multicolumn{2}{c}{ Oner and Aloglu [52] ${ }^{2}$} \\
\cline { 2 - 5 } Variables & $2 \mathrm{~d}$ & $90 \mathrm{~d}$ & $1 \mathrm{~d}$ & $90 \mathrm{~d}$ \\
\hline Water (\%) & 44.9 & 31.4 & 42.3 & 39.8 \\
Fat (\%) & 29.0 & 32.0 & 22.3 & 22.3 \\
Fat-in-dry matter (\%) & 51.8 & 46.6 & 38.6 & 37.4 \\
Protein (\%) & 17.5 & 20.7 & 22.7 & 23.0 \\
Salt (\%) & 4.1 & 7.9 & 4.5 & 9.9 \\
pH & 5.8 & 5.1 & 5.2 & 5.4 \\
Titratable acidity & 0.5 & 1.0 & 1.5 & 1.1 \\
WSN $(\%$ of TN) & 15.3 & 24.6 & 4.2 & 5.9 \\
ADV & 3.0 & 6.2 & - & - \\
\hline
\end{tabular}

${ }^{1}$ Raw cows' milk was used.

${ }^{2}$ Raw goats' milk was used.

${ }^{3}$ Expressed as g lactic acid per $100 \mathrm{~g}$ of cheese.

of $\mathrm{TN}$ ) is $5.9 \%$ at $90 \mathrm{~d}$ ). Due to inconsistency in the results in the literature, further studies are needed to better understand the basic characteristics of Mihalic cheese.

\section{EZINE CHEESE}

Ezine cheese is a white brined variety with a rectangular shape, similar to Beyaz peynir (Turkish white cheese). The cheese is produced by small-scale producers called "mandira" in Ezine, a county of Canakkale, using a mixture of sheep's, goats' and cows' milk at levels of 50, 40 and $10 \%$, respectively. However, this ratio of milks may vary according to the season. The cheesemaking season is from March to July, because sheep and goats give birth mainly in the spring. A designation "Protected Geographical Indication" for Ezine cheese was obtained in 2007 by the Association of Ezine Cheese Producers [1]. The manufacturing procedure for Ezine is similar to that for Beyaz peynir, but the geographical origin of the milk contributes some specialities to Ezine cheese. The milk, which is obtained from animals grazing on natural plant sources of Ezine, Bayramic, Ayvacik and some villages located in the north and west of Kaz Dagi (Mount Ida in Greek mythology) at an altitude of 1774 m, is used for the manufacture of Ezine cheese [43]. Many aromatic plants, including sweet marjoram (Origanum marjorana L.), oregano (Origanum vulgare), garden sage (Salvia officinalis L.), mint (Mentha lonifolia L), melisa (Melisa officinalis L.), thyme (Thymus vulgaris L.) and hundreds of other plant species grow on the Kaz Dagi. These plants play a crucial role in the development of the characteristic flavour of Ezine. Sea salt is used to brine Ezine and prevents softening and crumbliness in the cheese. The chemical and sensory properties of 22 samples of Ezine were studied by Karagul-Yuceer et al. [43]; moisture, titratable acidity, fat-in-dry matter, salt-in-dry matter were 48.2 to $56.9 \%$, 0.73 to $2.13 \%, 49.3$ to $58.8 \%$ and 5.6 to $11.9 \%$, respectively. The authors reported that Ezine cheese is characterized by a rancid, cooked, creamy, whey-like, goaty, salty and sour flavour and taste, and a soft or semi-hard texture. Some minerals were determined in 22 samples of Ezine cheese by Isleten et al. [38] and their concentrations were found to be 298.9-1025.6, 27.4-60.5, 0-0.06, 0.04-0.58, 8.5-38.6, 0$0.24,2.1-8.2 \mathrm{mg} \cdot 100 \mathrm{~g}^{-1}$ for $\mathrm{Ca}, \mathrm{Mg}, \mathrm{Mn}$, $\mathrm{Cu}, \mathrm{Al}, \mathrm{Cr}$ and $\mathrm{Zn}$, respectively. 


\section{ORGU CHEESE}

Orgu cheese is a brined variety produced in Diyarbakir province and its vicinity and it can be found in markets throughout Turkey. Its manufacturing protocol is similar to that for Kashar cheese, which is a pasta-filata type; however, it is ripened under brine, like Beyaz peynir, for more than 3 months [8]. The cheese is semi-hard and has a compact texture due to scalding and kneading, a salty taste and a yellowish colour. Orgu means "braided" like hair and kneading is performed after cooking the curds at $70-75{ }^{\circ} \mathrm{C}$ for $5-6 \mathrm{~min}$. The cheese is manufactured mainly from sheep's milk from April to June and it is consumed fresh or after ripening under brine. Raw sheep's milk is coagulated at $33-35^{\circ} \mathrm{C}$ using commercial calf rennet and the coagulum is cut after 30 to $120 \mathrm{~min}$ depending on the amount of coagulant added. The curds are transferred to a cloth bag $(20 \times 20 \mathrm{~cm})$ and drained for 5-6 h. Then, the curd block is cut into pieces using a knife or a cutter and is held for development of the desired $\mathrm{pH}$ (5.0-5.1). The pieces of curd are cut again and scalded in water (or $3 \% \mathrm{NaCl}$ brine) at $70-75{ }^{\circ} \mathrm{C}$ for $5 \mathrm{~min}$. The scalded curd is stretched into strings $1 \mathrm{~cm}$ in diameter and three strings are wound together and cut into pieces approximately $10 \mathrm{~cm}$ in length. The pieces of curd are dry-salted, placed in a metal or plastic container and held overnight. The following day, the pieces of cheese are covered with $12-15 \% \mathrm{NaCl}$ and the containers closed with a lid. The cheese is ripened in these containers in a cold room for at least 3 months $[8,75,77]$. The mean chemical composition of 29 samples of Orgu cheese was as follows: moisture $52.3 \%$, fat $17.9 \%$, protein $20.0 \%$, salt $5.3 \%$ and titratable acidity $1.1 \%$ (lactic acid) [75]. Microbial counts $\left(\log \mathrm{cfu} \cdot \mathrm{g}^{-1}\right)$ for Orgu cheese are high; total mesophilic bacteria 5.59 to 8.37, coliform 0 to 6.06 , lactic acid bacteria 4.67 to 7.94 , yeasts and moulds 3.30 to 7.45 .
Ozdemir et al. [54] reported that 16 samples of Orgu cheese contained the following elements (mean values, $\mathrm{mg} \cdot 100 \mathrm{~g}^{-1}$ ) $\mathrm{Ca}$ (459.0), Na (2731.5), K (153.8), P (368.7) and $\mathrm{Mg}$ (40.8).

\section{CIVIL CHEESE}

Civil is produced as both an acid and rennet curd cheese and is very popular in eastern regions of Turkey. The cheese is produced in Caucasus countries and Armenia under the name "Cecil" [76]. It is characterized by a fibrous appearance, a low fat content and a plastic texture due to kneading during manufacture. Traditional Civil cheese is made from skim milk or whey. The cheese milk is pre-ripened overnight at about $15{ }^{\circ} \mathrm{C}$ to develop acidity by its natural microflora until $\mathrm{pH} 5.3$ 5.4 ( $0.5 \%$ lactic acid) is reached. The acidity can be adjusted to the desired $\mathrm{pH}$ by adding unripened skim milk. The acidity of the cheese milk affects its microbial quality [79] and textural characteristics. After the desired acidity has been reached, the skim milk is heated to $30{ }^{\circ} \mathrm{C}$ and calf rennet is added $(4 \mathrm{~mL}$ per $100 \mathrm{~L}$ skim milk), with gentle stirring. Then, the temperature is increased, with gentle stirring, to $70{ }^{\circ} \mathrm{C}$ (curds form at about $50-53{ }^{\circ} \mathrm{C}$ ) and the curds are collected using a paddle. The collected curds are placed on a table and kneaded by hand for 3-5 min. After kneading, the body of curds is hung from a platform for stretching under its own weight and the stretching process is repeated until the curd has a smooth, plastic and fibrous texture. Following stretching, the cheese is cut into $12 \mathrm{~cm}$ pieces and brined in $9 \% \mathrm{NaCl}$ brine for ripening [67, 80]. The chemical composition of 15 samples of Civil cheese, determined by Sengul et al. [67], was as follows (mean values): moisture, $63.9 \%$; fat-in-dry matter, $5.81 \%$; salt, $0.2 \%$; titratable acidity, $1.3 \%$ and total nitrogen (TN), 4.4\%. The level 
of proteolysis (as \% of TN) was fairly low, i.e., WSN, 5.9\%; TCA-SN, $4.3 \%$ and PTA$\mathrm{SN}, 2.0 \%$ [67]. Similar results were obtained for $60 \mathrm{~d}$ [12] or $180 \mathrm{~d}$-old Civil cheeses [80]. No substantial degradation of nitrogen fractions was shown by gel electrophoresis of Civil $[67,80]$. It is fair to conclude from the data that hydrolysis of casein in Civil cheese is usually lower than in other brined varieties. Civil cheeses ( $n=$ 6) collected from retail outlets contained high levels of histamine and tyramine, with average values of $94.76 \mathrm{mg} \cdot 100 \mathrm{~g}^{-1}$ and $138.16 \mathrm{mg} \cdot 100 \mathrm{~g}^{-1}$, respectively; these values were much higher than the acceptable limits [15]. In another study by Yetismeyen [83], Civil cheeses $(n=20)$ contained lower levels of biogenic amines, including tyramine $\left(0.88 \mathrm{mg} \cdot 100 \mathrm{~g}^{-1}\right)$, histamine $\left(0.15 \mathrm{mg} \cdot 100 \mathrm{~g}^{-1}\right)$ and cadaverin $\left(0.22 \mathrm{mg} \cdot 100 \mathrm{~g}^{-1}\right)$. Civil cheese had high microbial counts (as mean $\log \mathrm{cfu} \cdot \mathrm{g}^{-1}$ ), i.e., total bacteria, 8.47; yeasts and moulds, 6.3; lactic acid bacteria, 7.5 and coliform (in coliform-positive samples), 4.62 [66]. Sert and Kivanc [68] found high numbers of pathogenic and non-pathogenic contaminants in Civil cheese, including $S$. aureus, E. coli, coliforms, yeasts and moulds. Sengul [66] identified 72 strains of Lactobacillus isolated from Civil cheese; these were mainly $L b$. malefermentans (20 isolates), Lb. fermentum (18 isolates), Lb. parabuchneri (17 isolates) and Lb. vaccinostercus (10 isolates).

\section{DIL CHEESE}

Dil is a semi-hard cheese with a characteristic fibrous texture. Its shape resembles a tongue, therefore, the name "dil", which means "tongue" in Turkish. It is usually made from pasteurized cows' milk to which a thermophilic lactic culture is added. The milk is coagulated at $33-35^{\circ} \mathrm{C}$ for about $60 \mathrm{~min}$. The coagulum is cut into small cubes, rested for 5-10 min and a portion ( $40 \%$ of the cheese milk) of whey is removed and the curds held for a further $30 \mathrm{~min}$. Afterwards, the remaining whey is removed and the curds are pressed until the desired acidity ( $\mathrm{pH}$ 5.0-5.2) is reached. The acidified curd is cut into pieces by hand or a cutter and cooked in hot water or $5 \% \mathrm{NaCl}$ brine at $80-90{ }^{\circ} \mathrm{C}$. The hot curd is kneaded and stretched to form longitudinal fibres. The elastic curd is extended manually, cooled in cold water and cut into cylindrical pieces, $2-3 \mathrm{~cm}$ in diameter and $8-15 \mathrm{~cm}$ long. The pieces are immersed in $10 \% \mathrm{NaCl}$ brine at $25^{\circ} \mathrm{C}$. Salted Dil cheese is packaged under vacuum and sold, usually without ripening $[49,77]$. The mean chemical composition of 42 samples of Dil cheese was as follows: total solids, $50.4 \%$; fat, $21.6 \%$; protein, $25.8 \%$; salt, $1.8 \%$ and titratable acidity, $0.7 \%$ (lactic acid). The $\mathrm{pH}$ of the samples ranged from 4.9 to 5.6 [49]. The proteolysis indices (as \% of TN) were: WSN, 5.6 to $24.8 \%$; TCA-SN, 2.7 to $9.6 \%$; and PTA$\mathrm{SN}, 1.5$ to $3.7 \%$ [50]. This wide variation may be attributed to the low level of salt in the cheese and the unknown age of the samples analyzed.

\section{GAZIANTEP CHEESE}

Gaziantep cheese is a brined, semi-hard variety produced in southern Turkey. The cheese is sold immediately after production or immersed in brine for ripening. Gaziantep cheese is made from pasteurized cows', sheep's or goats' milk or mixtures of these milks; it has a spherical shape, with a diameter of 6-10 cm. After pasteurization, the cheese milk is cooled to about $35{ }^{\circ} \mathrm{C}$ and coagulated within $60 \mathrm{~min}$. Then, the coagulum is cut into pieces, stirred and transferred to a cloth for draining by gravity. The curd is drained overnight or the curd is pressed by curling the cloth. Then, the curd is shaped by hand and scalded at $80-90{ }^{\circ} \mathrm{C}$ for $1 \mathrm{~min}$ 
and shaped again $[39,48]$. The curds are immersed in 20-25\% NaCl brine for up to 1 year [47] and the cheese has a very salty taste. However, increasing the level of salt ( $>20 \% \mathrm{NaCl}$ brine) causes some textural [47] and hydrolytic and oxidative rancidity problems [48] in Gaziantep cheese. Reduction of the fat-in-dry matter content (FDM, 50.4, 33.4 or 13.5\%) and scalding the curd at different temperatures $\left(75,85\right.$ or $\left.95^{\circ} \mathrm{C}\right)$ affected the rheological and functional properties of Gaziantep cheese $[39,40]$. Reducing the fat-in-dry matter and increasing the scalding temperature improved the textural characteristics of the cheese, including hardness, gumminess, cohesiveness and springiness values, while these treatments reduced the meltability of Gaziantep cheese. The typical composition of $14 \mathrm{~d}$-old Gaziantep cheese brined in $20 \% \mathrm{NaCl}$ brine is $46.9 \%$ moisture, $8.9 \%$ salt, $24.2 \%$ fat and $17.1 \%$ protein [47].

\section{MARAS CHEESE}

Traditional Maras (also named Sikma) cheese is made from pasteurized sheep's or goats' milk. After pasteurization, the cheese milk is cooled to $30{ }^{\circ} \mathrm{C}$ for coagulation, and the coagulum is cut after $80 \mathrm{~min}$ into $3 \mathrm{~cm}$ cubes and pressed (20 kg weights per $100 \mathrm{~kg}$ milk) for about $60 \mathrm{~min}$. The curd is held for about $10 \mathrm{~h}$ (or overnight) at $22-24{ }^{\circ} \mathrm{C}$ to develop acidity (1.0-1.4\% as lactic acid). Then, the mass of curd is cut into small portions $(5 \times 3.5 \times 2 \mathrm{~cm})$ and cooked at $65-70{ }^{\circ} \mathrm{C}$ for $10 \mathrm{~min}$. The cooked curds are shaped by hand and dry-salted. The following day, the cheese pieces are immersed in $12-13 \% \mathrm{NaCl}$ brine and ripened at $6-10{ }^{\circ} \mathrm{C}$ for 2 months $[70,71]$. Ninety day-old Maras cheeses were found to contain $42-45 \%$ moisture, $40-41 \%$ fat-indry matter, 14-15\% salt-in-dry matter and 5.0-5.1 pH [71]. Ceylan et al. [13], who analyzed 34 samples of Maras cheese, found high counts of coliforms (4.0 to $7.4 \log \mathrm{cfu} \cdot \mathrm{g}^{-1}$ ), total bacteria (5.9 to $\left.8.7 \mathrm{log} \mathrm{cfu} \cdot \mathrm{g}^{-1}\right)$, and yeasts and moulds (2.7 to $6.4 \log \mathrm{cfu} \cdot \mathrm{g}^{-1}$ ).

\section{CONCLUDING REMARKS}

More than 50 varieties of cheese are produced in Turkey [32]; however, brined cheeses are well established products in the diet of Turkish people. With the exception of a few varieties, most of the traditional brined cheeses have not yet been industrialised. Relatively little is known about the basic characteristics of the brined cheeses native to Turkey. Investigation and documentation of the basic parameters of brined cheeses, including texture/rheology, structure and sensory properties are important for achieving consumer-oriented modifications in these products (i.e., low-salt, reduced-fat analogues of brined cheeses). Although a number of studies have been undertaken to characterize Turkish brined cheeses, there are still many areas that need to be investigated further:

- The isolation, identification and characterization of microorganisms present in traditional brined cheeses made from raw or pasteurized milk should be studied and new starter culture combinations, including salt-tolerant strains, should be developed.

- Processing conditions such as brine concentration, temperature and $\mathrm{pH}$ should be optimized. Also, the kinetics of salt absorption and diffusion during the maturation of the cheeses needs to be fully understood in order to standardize the salting conditions.

- Products of proteolysis and lipolysis should be identified and these parameters should be used as selection criteria for starter culture combinations.

- Automation and mechanization techniques should be developed so that industrialization of traditional brined cheeses would be possible. 


\section{REFERENCES}

[1] Anonymous, http://www.ezine.gov.tr/show.php? page $=$ peynir (online access on 20 February, 2007).

[2] Abd El-Salam M.H., Alichanidis E., Cheese varieties ripened in brine, in: Fox P.F., McSweeney P.L.H., Cogan T.M., Guinee T.P. (Eds.), Cheese: Chemistry, Physics and Microbiology, Elsevier Academic Press, London, 2004, pp. 227-249.

[3] Akalin A.S., Gonc S., Akbas Y., Variation in organic acids content during ripening of pickled white cheese, J. Dairy Sci. 85 (2002) 1670-1676.

[4] Akbulut N., Gonc S., Kinik O., Uysal H.R., Akalin S., Kavas G., Bazi tuzlama yontemlerinin beyaz peynir uretiminde uygulanabilirligi ve peynir kalitesi uzerine arastirmalar. II. Kimyasal ozellikler uzerine etkileri, Ege Universitesi Ziraat Fakultesi Dergisi 33 (1996) 17-24.

[5] Akgun S., Utilisation de souche de Lactobacillus sake comme culture de ferments pour la fabrication de fromage blanc, Ankara Universitesi Veteriner Fakultesi Dergisi 42 (1997) 271-279.

[6] Akin M.S., Sahan N., Sanliurfa'da uretilen taze Urfa peynirlerinin kimyasal ve duyusal ozelliklerinin belirlenmesi uzerine bir arastirma, in: 5. Sut ve sut urunleri sempozyumu, Tekirdag, Turkey, 1988, pp. 282296.

[7] Aksoydan M., Beyaz peynire islenen sutlerde protein-yag oranlarinin ve olgunlasmanin peynirde kalite ve randimana etkileri, M.Sc. thesis, Cukuorva University, Adana, Turkey, 1996.

[8] Akyuz N., Tutsi M.F., Mengel Z., Ocak E., Altun I., Orgu peynirinin uretim teknigi, bazi mikrobiyolojik ve kimyasal ozellikleri, in: 5 . Sut ve sut urunleri sempozyumu, Tekirdag, Turkey, 1988, pp. 328-337.

[9] Anifantakis E.M., Moatsou G., Feta and other Balkan cheeses, in: Tamime A. (Ed.), Brined cheeses, Blackwell Publishing Ltd, Oxford, UK, 2006, pp. 43-76.

[10] Atasever M., Keles A., Ucar A., Guner A., Use of different salting techniques in Halloumi cheese: effect on sensory, microbiological and chemical properties, Acta Alimentaria 32 (2003) 7-14.

[11] Atasoy A.F., Akin M.S., Sanliurfa ilinde satisa sunulan Urfa peynirlerinin bazi kimyasal ozellikleri ve proteoliz duzeylerinin belirlenmesi uzerine bir arastirma, Harran Universitesi Ziraat Fakultesi Dergisi 8 (2004) 9-15.

[12] Caglar A., Kurt A., Ceylan Z.G., Hursit S., Civil peynirinin farkli sekillerde muhafazasi uzerine arastirmalar, in: 5 . Sut ve sut urunleri sempozyumu, Trakya Universitesi, Tekirdag, Turkey, 1998, pp. 65-78.

[13] Ceylan Z.G., Turkoglu H., Dayisoylu K.S., The microbiological and chemical quality of Sikma cheese produced in Turkey, Pakistan J. Nutr. 2 (2003) 95-97.

[14] Coskun H., Otlu peynir, Gida Teknolojisi Dernegi Yayinlari, No. 31, Ankara, Turkey, 2005.

[15] Durlu-Ozkaya F., Biogenic amine content of some Turkish cheeses, J. Food Process. Preserv. 26 (2002) 259-265.

[16] Durlu-Ozkaya F., Xanthopoulos V., Tunail N., Litopoulou-Tzanetaki E., Technologically important properties of lactic acid bacteria isolates from Beyaz cheese made from raw ewes' milk, J. Appl. Microbiol. 91 (2001) 861-70.

[17] Ekici K., Coskun H., Tarakci Z., Ondul E., Sekeroglu R., The contribution of herbs to the accumulation of histamine in "Otlu" cheese, J. Food Biochem. 30 (2006) 362371.

[18] Eralp M., Peynir Teknolojisi, Ankara Universitesi Ziraat Fakultesi Yayinlari, Ankara, Turkey, 1974.

[19] Erkmen O., Survival of Listeria monocytogenes during the manufacture and ripening of Turkish white cheese, Nahrung 45 (2001) 55-58.

[20] Gencer N., Ultrafiltre koyun ve keci sutlerinin ve telemelerinin bazi nitelikleri uzerine farkli pastorizasyon normlari ve pihtilaştirici enzimlerin etkisi, Ph.D. thesis, Ankara University, Ankara, Turkey, 2003.

[21] Guler Z., Uraz T., Relationship between proteolytic and lipolytic activity and sensory properties (taste-odour) of traditional Turkish white cheese, Int. J. Dairy Technol. 57 (2004) 237-242.

[22] Guley Z., Akbulut N., Effects of using starter culture on some properties of Halloumi cheese, in: Proceedings of Symposium, Recent Development in Dairy Science and Technology, International Dairy Symposium, 24-28 May, Isparta, Turkey, 2004, pp. 222-225. 
[23] Gursel A., Gursoy A., Senel E., Deveci O., Karademir E., The use of freeze-shocked lactic starters in low-fat white pickled cheese, Milchwissenschaft 58 (2003) 279-282.

[24] Gursoy A., Gursel A., Senel E., Deveci O., Karademir E., Yag icerigi azaltilmis beyaz peynir uretiminde isil islem uygulanan Lactobacillus helveticus ve Lactobacillus delbrueckii subsp. bulgaricus kulturlerinin kullanimi, in: GAP II. Tarim Kongresi Bildiriler Kitabi, Harran Universitesi, Sanliurfa, Turkey, 2001, pp. 269-278.

[25] Guven M., Cadun C., Karaca O.B., Hayaloglu A.A., Influence of rennet concentration on ripening characteristics of Halloumi cheese, J. Food Biochem. (2007) (accepted).

[26] Guven M., Karaca O.B., Proteolysis levels of White cheeses salted and ripened in brines prepared from various salts, Int. J. Dairy Technol. 54 (2001) 29-33.

[27] Guven M., Karaca O.B., Hayaloglu A.A., Farkli tuzlardan hazirlanan salamuralarda tuzlanan ve olgunlastirilan Beyaz peynirlerin ozellikleri, in: GAP II. Tarim Kongresi Bildiriler Kitabi, Harran University, Sanliurfa, Turkey, 2001, pp. 401-410.

[28] Guven M., Yerlikaya S., Hayaloglu A.A., Influence of salt concentration on the characteristics of Beyaz cheese, a Turkish white brined cheese, Lait 86 (2006) 73-81.

[29] Hayaloglu A.A., Comparisons of different single-strain starter cultures for their effects on ripening and grading of Beyaz cheese, Int. J. Food Sci. Technol. 42 (2007) 930-938.

[30] Hayaloglu A.A., Brechany E.Y., Influence of milk pasteurization and scalding temperature on the volatile compounds of Malatya, a farmhouse Halloumi-type cheese, Lait 87 (2007) 39-57.

[31] Hayaloglu A.A., Fox P.F., Cheeses of Turkey: 3. Varieties containing herbs or spices, Dairy Sci. Technol. 88 (2008) 245256.

[32] Hayaloglu A.A., Fox P.F., Guven M., Cakmakci S., Cheeses of Turkey: 1. Varieties ripened in goat-skin bags, Lait 87 (2007) 79-95.

[33] Hayaloglu A.A., Guven M., Fox P.F., Microbiological, biochemical and technological properties of Turkish white cheese "Beyaz Peynir", Int. Dairy J. 12 (2002) 635648.

[34] Hayaloglu A.A., Guven M., Fox P.F., Hannon J.A., McSweeney P.L.H., Proteolysis in Turkish white brined cheese made with defined strains of Lactococcus, Int. Dairy J. 14 (2004) 599-610.

[35] Hayaloglu A.A., Guven M., Fox P.F., McSweeney P.L.H., Influence of starters on chemical, biochemical and sensory changes in Turkish white brined cheese during ripening, J. Dairy Sci. 88 (2005) 3460-3474.

[36] Hosono A., Iseki Y., Otani H., Takahashi F., Identification of lactic acid bacteria in "Beyaz Peynir" a traditional cheese in Turkey, Anim. Sci. Technol. 63 (1992) $712-$ 714.

[37] Ince H., Cildam T., Ozbag M., Hellim peyniri, in: 5. Sut ve sut urunleri sempozyomu, Trakya University, Tekirdag, Turkey, 1998, pp. 89-95.

[38] Isleten M., Uysal-Pala C., Karagul-Yuceer Y., Ezine peynirinin mineral madde icerigi, Gida 32 (2007) 173-179.

[39] Kahyaoglu T., Kaya S., Effects of heat treatment and fat reduction on the rheologial and functional properties of Gaziantep cheese, Int. Dairy J. 13 (2003) 867-875.

[40] Kahyaoglu T., Kaya S., Kaya A., Effect of fat reduction and curd dipping temperature on viscoelasticity, texture and appearance of Gaziantep cheese, Food Sci. Technol. Int. 11 (2005) 191-198.

[41] Kamber U., Geleneksel Anadolu Peynirleri, Miki Matbaacilik, Ankara, Turkey, 2005.

[42] Kaptan B., Simsek O., Kurultay S., The effect of non-starter Enterococcus spp. on some properties of white pickled cheese, Milchwissenschaft 61 (2006) 308-311.

[43] Karagul-Yuceer Y., Isleten M., Uysal-Pala C. Sensory characteristics of Ezine cheese, J. Sens. Stud. 22 (2007) 49-65.

[44] Karakus M., Beyaz peynirlerden izole edilen laktik asit bakterilerinin asit olusturma ve proteolitik aktiviteleri, Gida 19 (1994) 237241.

[45] Karakus M., Borcakli M., Alperden I., Beyaz peynirin olgunlasmasi surecinde laktik asit bakterileri, Gida 17 (1992) 363-369.

[46] Kasimoglu A., Goncuoglu M., Akgun S., Probiotic white cheese with Lactobacillus acidophilus, Int. Dairy J. 14 (2004) 10671073.

[47] Kaya S., Effect of salt on hardness and whiteness of Gaziantep cheese during short-term brining, J. Food Eng. 52 (2002) 155-159.

[48] Kaya S., Kaya A., Oner M.D., The effect of salt concentration on rancidity in Gaziantep cheese, J. Sci. Food Agric. 79 (1999) 213219. 
[49] Kilic M., Isin T.G., Effects of salt level and storage on texture of Dil cheese, J. Texture Stud. 35 (2004) 251-262.

[50] Kocak C., Aydinoglu G., Uslu K., Ankara piyasasinda satilan Dil peynirlerinin proteoliz duzeyi uzerinde bir arastirma, Gida 22 (1997) 251-255.

[51] Milci S., Goncu A., Alpkent Z., Yaygin H., Chemical, microbiological and sensory characterization of Halloumi cheese produced from ovine, caprine and bovine milk, Int. Dairy J. 15 (2005) 625-630.

[52] Oner Z., Aloglu H., Some characteristics of Mihalic: a traditional Turkish cheese, Milchwissenschaft 59 (2004) 628-631.

[53] Ozcan T., Starter, proteaz ve lipaz kullaniminin Mihalic peynirinin olgunlasma suresine etkisi, Ph.D. thesis, Uludag University, Bursa, Turkey, 2000.

[54] Ozdemir S., Celik S., Ozdemir C., Sert S., Diyarbakir'in Karacadag yoresinde mahalli olarak yapilan Orgu peynirinin mikrobiyolojik ve kimysal ozellikleri, in: 5. Sut ve sut urunleri sempozyumu, Trakya Universitesi, Tekirdag, Turkey, 1998, pp. 154-159.

[55] Ozer B.H., Atamer M., Turkoglu H., Senel E., Kirmaci H.A., Oztekin S., Survival of Lb. acidophilus LA-5 and B. bifidum BB-12 microencapsulated by emulsion or extrusion techniques in white brined Turkish cheese, TUBITAK Project No: TOVAG 3227, Final Report, 2006.

[56] Ozer B., Atasoy A.F., Akin M.S., Pastorizasyon ve haslama islemlerinin geleneksel Urfa peynirlerinin mikrobiyolojik ve kimyasal nitelikleri uzerine etkileri, in: 6. Sut ve sut urunleri sempozyumu, Trakya Universitesi, Tekirdag, Turkey, 2000, pp. 517-523.

[57] Ozer B., Atasoy F., Akin S., Some properties of Urfa cheese (a traditional white-brined Turkish cheese) produced from bovine and ovine milks, Int. J. Dairy Technol. 55 (2002) 94-99.

[58] Ozer B.H., Robinson R.K., Grandison A.S., Textural and microstructural properties of Urfa cheese (a white-brined Turkish cheese), Int. J. Dairy Technol. 56 (2003) 171-176.

[59] Ozer H.B., Uraz G., Beyzi-Yilmaz E., Atasoy A.F., The effects of brine concentration and scalding on survival of some pathogens in Urfa cheese: a traditional white-brined Turkish cheese, Int. J. Food Sci. Technol. 39 (2004) 727-735.

[60] Papademas P., Halloumi cheese, in: Tamime A. (Ed.), Brined cheeses, Blackwell
Publishing Ltd, Oxford, UK, 2006, pp. 116-138.

[61] Papademas P., Robinson R.K., Halloumi cheese: The product and its characteristics, Int. J. Dairy Technol. 51 (1998) 98-103.

[62] Papademas P., Robinson R.K., Some volatile plant compounds in Halloumi cheeses made from ovine or bovine milk, Lebensm.-Wiss. Technol. 35 (2002) 512-516.

[63] Robinson R.K., Tamime A.Y., Feta and related cheeses, Ellis Horwood Limited, New York, USA, 1991.

[64] Saldamli I., Kaytanli M., Utilization of Fromase, Maxiren and Rennilase as alternative coagulating enzymes to rennet in Turkish white cheese, Milchwissenschaft 53 (1998) 22-25.

[65] Sen M.K.C., Temelli S., Saltan Evrensel S., Mihalic peynirlerinin yapimi ve olgunlasmasi sirasinda Yersinia enterocolitica'nin canli kalabilme yeteneginin incelenmesi, Tr. J. Vet. Anim. Sci. 27 (2003) 1029-1034.

[66] Sengul M., Microbiological characterization of Civil cheese, a traditional Turkish cheese: microbiological quality, isolation and identification of its indigenous lactobacilli, World J. Microbiol. Biotechnol. 22 (2006) 613618

[67] Sengul M., Gurses M., Dervisoglu M., Yazici F., A survey on the some chemical and biochemical properties of Civil cheese, a traditional Turkish cheese, J. Food Prop. 9 (2006) 791-801.

[68] Sert S., Kivanc M., Taze Civil ve Lor peynirleri uzerinde mikrobiyolojik calismalar, Gida 5 (1985) 287-292.

[69] Tarakci Z., Coskun H., Tuncturk Y., Some properties of fresh and ripened herby cheese, a traditional variety produced in Turkey, Food Technol. Biotechnol. 42 (2004) 47-50.

[70] Tekinsen K.K., Nizamlioglu M., Maras peyniri uretiminde baskilama agirligi ve haslama sicakliginin bazi kalite niteliklerine etkisi, Tr. J. Vet. Anim. Sci. 27 (2003) 153160.

[71] Tekinsen O.C., Sut Urunleri Teknolojisi, Selcuk Universitesi Veteriner Fakultesi Yayinlari, Konya, Turkey, 1997.

[72] Toufeili I., Ozer B.H., Brined Cheeses from the Middle East and Turkey, in: Tamime A.Y. (Ed.), Brined Cheeses, Blackwell Publishing Ltd, Oxford, UK, 2006 pp. 188-210.

[73] Turantas F., Unluturk A., Goktan D., Microbiological and compositional status of Turkish white cheese, Int. J. Food Microbiol. 8 (1989) 19-24. 
[74] Turhan M., Kaletunc G., Modelling of salt diffusion in White cheese during long term brining, J. Food Sci. 57 (1992) 1082-1085.

[75] Turkoglu H., Ceylan Z.G., Dayisoylu K.S., The microbiological and chemical quality of Orgu cheese produced in Turkey, Pakistan J. Nutr. 2 (2003) 92-94.

[76] Ucuncu M., A'dan Z'ye Peynir Teknolojisi, Meta Basim Matbaacilik, Izmir, Turkey, 2004.

[77] Unsal A., Sut Uyuyunca-Turkiye Peynirleri, Yapi Kredi Yayinlari, Istanbul, Turkey, 2003.

[78] Uysal H.R., Kinik O., Akbulut N., Research on the possibilities of the use of chicken pepsine for the manufacture of white-brined cheese, Ege Universitesi Ziraat Fakultesi Dergisi 33 (1996) 99-106.

[79] Yazici F., Effect of $\mathrm{pH}$ on microflora of Civil cheese during refrigerated storage, Acta Alimentaria 33 (2004) 201-206.

[80] Yazici F., Dervisoglu M., Effect of pH adjustment on some chemical, biochemical, and sensory properties of Civil cheese during storage, J. Food Eng. 56 (2003) 361-369.
[81] Yesilyurt S., Studies on the use of Fromase and Rennilase from Rhizomuchor miehei in white cheese, Ph.D. thesis, Ege University, Izmir, Turkey, 1992.

[82] Yetismeyen A., Ultrafiltre sutten beyaz peynir uretiminin arastirilmasi, Gida 12 (1987) 13-17.

[83] Yetismeyen A., Bazi geleneksel peynirlerimizin biyojen amin içeriginin saptanmasi ve peynirlerin mikrobiyolojik, kimyasal ozellikleriyle olan iliskisinin arastirilmasi, Ankara University Scientific Research Project Report, Ankara, Turkey, 2005.

[84] Yetismeyen A., Cimer A., Ozer M., Odabasi S., Deveci O., Ultrafiltrasyon teknigi ile salamura beyaz peynir uretiminde kalite uzerine degisik maya enzimlerinin etkisi, Gida 23 (1998) 3-9.

[85] Yilmaztekin M., Ozer B.H., Atasoy A.F., Survival of Lactobacillus acidophilus LA-5 and Bifidobacterium bifidum BB-02 in white-brined cheese, Int. J. Food Sci. Nutr. 55 (2004) 53-60. 